\title{
GCU
}

Glasgow Caledonian

University

University for the Common Good

\section{Experiencing fashion: the interplay between consumer value and sustainability}

\author{
Ritch, Elaine L.
}

Published in:

Qualitative Market Research: An International Journal

DOI:

10.1108/QMR-09-2019-0113

Publication date:

2020

Document Version

Author accepted manuscript

Link to publication in ResearchOnline

Citation for published version (Harvard):

Ritch, EL 2020, 'Experiencing fashion: the interplay between consumer value and sustainability', Qualitative Market Research: An International Journal, vol. 23, no. 2, pp. 265-285. https://doi.org/10.1108/QMR-09-20190113

\section{General rights}

Copyright and moral rights for the publications made accessible in the public portal are retained by the authors and/or other copyright owners and it is a condition of accessing publications that users recognise and abide by the legal requirements associated with these rights.

Take down policy

If you believe that this document breaches copyright please view our takedown policy at https://edshare.gcu.ac.uk/id/eprint/5179 for details of how to contact us. 


\title{
Experiencing fashion: The interplay
}

\section{between consumer value and}

\section{sustainability}

\begin{abstract}
Purpose - The purpose of this study is to explore consumers perceptions of sustainability, including how information is accessed, evaluated and practiced, and how sustainability concepts transfer to fashion consumption.
\end{abstract}

Design - The research adopts a phenomenological approach of unstructured interviews with 28 professionally working mothers. Garment labels indicating concepts of sustainability from UK fashion-retailers were used as a vehicle for discussion. Data were analysed through the theoretical lens of Holbrook's (1999) Typology of Consumer Value.

Findings - The findings identity that the participants struggle with understanding how sustainability is compromised within fashion-production and how their sustainability practice fluctuates depending on information, guidance and practical support. The findings also identify preferences for sustainability where sustainable concepts are perceived as adding value.

Research limitations/implications - Limitations are assumed through the small focused sample; however, the research does provide rich insight into individual experiences to better understand how everyday deliberations of household management and sustainability concepts are practiced.

Practical implications - The findings illustrate pathways for retailers, producers and policymakers to guide sustainability and support sustainability through the use of labels and marketing which will enhance notions of value. Similarly, the findings can enable policy makers to position campaigns and practical solutions that advance the sustainability agenda.

Social implications - The research indicates that sustainability is filtering through society and drawing the attention of a broader consumer market, including mainstream consumers who are developing expectations that mainstream fashion-retailers address sustainability.

Originality/value - The research is novel in adopting a phenomenological approach that provides a unique insight into how sustainability is experienced in everyday households, through the adaptation of related behaviours and evaluating sustainability concepts. 
Key words: Sustainability, fashion, consumer value, household, recycling, production, consumption, exploitation

\section{Introduction}

Sustainability extends from global governance to consumer action groups; businesses are recognising the benefits of addressing sustainability to gain competitive advantage in the marketplace (Davies and Gutsche, 2016). Sustainability is progressing from niche markets into mainstream consciousness, nudging consumers typically disinterested. Meanwhile, the fashion-industry does little to address sustainability (Hinsliff, 2019), leaving consumers to navigate the implications of their consumption (Ritch and Brownlie, 2016). This world of fashion presents a paradox as to what underpins sustainability; new collections featuring changes in style and colour palettes reiterate that fashion is 'made to be unfashionable' (Chanel, cited in Davies, 1994: 162). As such, it is transitory and ephemeral whereas sustainability is lasting to encourage protection of natural sources and fairness for those who work in the industry (World Commission for Environment and Development, 1987). This positions fashion-values and sustainability-values at opposite ends of the spectrum.

There is insufficient information on sustainable-consumption behaviours (Davies and Gutsche, 2016). Often sustainable-consumption comes at a higher price, with inferior product attributes (Bray et al., 2011) and less choice, particularly for fashion, where sustainablefashion is considered as 'hippyish' (Ritch, 2015). This positions competing values of fashion and sustainability at odds with one another and offers nothing as to how fashion and sustainability values can be aligned for consumers (Chaney et al., 2018). Consequently, this research aims to provide insight into how consumers experience values in both sustainability and fashion to determine whether alignment can be created.

Despite Hirshman and Holbrook introducing the concept of consumer experience over 36 years ago (Chaney et al., 2018) it has received limited attention (Becker, 2018). More recently, Leroi-Werelds (2019) argued that given the vast change in the marketplace over the last few decades, consumer values have not been empirically updated to reflect individual situational experiences. Yet, there is much to learn about the everyday deliberations of household consumption, how it is experienced and how this informs other consumption contexts, such as fashion. Underpinning this is Holbrook's Typology of Consumer Value (TCV)(1999) to examine how value is experienced when purchasing fashion and what values take precedence over sustainability. Adopting an experiential approach enables the encapsulation of utilitarian and hedonistic values that form the overall consumption experience (Chaney et al., 2018). Becker (2018) posits that experiences will include multiple actors and resources that will inform consumption behaviours. Therefore, this research responds to Leroi-Werelds (2019) assertion that TCV constructs require renewed attention.

The research emerges out of a fashion context where the price of fashion in the UK has been falling steadily (Hinsliff, 2019), reducing the threshold and placing price as a core component of decision-making (Ritch, 2015). In order to examine consumer interpretations of sustainable-fashion, garment labels from UK fashion-retailers were utilised as a vehicle for discussion (Pink, 2005). This resulted in a better understanding of which values contribute to 
decision-making and engagement with sustainability. Little is known of how this transfers to fashion consumption. A deeper insight would provide guidance on how best to position marketing activities to encourage sustainability, as well as what further communication consumers require from retailers, producers and policy makers. Therefore, the following objectives will support the above aim:

- How do mainstream consumers evaluate facets of sustainability in their everyday lifeworlds?

- How are values negotiated and traded within household fashion consumption?

- At which point can fashion and sustainability values align?

The literature review will outline the definition of sustainability used to frame the research contextualised within the current fashion-industry. Thereafter, the TCV is explained and applied to relevant fashion consumption literature; the methodology is outlined and the findings are presented, concluding with implications for marketing, limitations of the research and opportunities for further research.

\section{Literature Review}

Although the fashion-industry makes significant contributions to the global economy, it impacts greatly on the earth's resources (Gupta et al., 2019). Global industrialisation has led to production in developing countries, where low production costs are allegedly the result of exploitative practice, of both garment-workers' conditions, wages and the ecological environment (Bick, 2018). The environment is overlooked, waste is not disposed of responsibly, thereby infiltrating water sources and soil, resulting in contamination (Rivoli, 2009). The World Commission for Economic Development (1987) describe sustainability as 'development that meets the needs of the present without compromising the ability of future generations to meet their own needs'. As such, businesses should acknowledge economic viability alongside the impact on environmental, ecological and social justice. As understanding of sustainability and business practice evolves, 17 sustainable development goals have been identified that include clean water and sanitation, decent work and economic growth, reduced inequality and responsible consumption and production (Mutum et al., 2019). This suggests that the fashion industry is not addressing shared sustainability goals for all stakeholders (including future generations, suppliers and wider social communities), positioning sustainability as an axiological issue, that of an ethical and moral perspective (Bolis et al., 2014). Do consumers indirectly contribute to poverty through benefiting from low-cost fashion? (Memery et al., 2005). The fashion-industry perpetuates unsustainableconsumption, despite having the potential to make a positive contribution. As lower pricing enables increased consumption, garments are not repaired when damaged and rapidly evolving fashion trends encourage planned obsolescence, resulting in a tendency towards disposal, much of which ends in landfill (Bick, 2018). Simply put: accelerated fashionproduction impacts on the environment and garment-workers who work long hours to fulfil orders for ever-evolving fashion trends, which in turn encourages consumers to buy more frequently, discarding garments to landfill after limited wear. This constrains the sustainability agenda: scarce resources are excavated for nominal use and increased consumption impacts negatively upon the environment. In particular, due to the geographical 
location of developing countries, their dependence on agriculture for economic prosperity and increasing levels of poverty, developing countries are financially ill-equipped to combat the consequences (Stern, 2006).

Complexity arises from adopting an ethical lens, as consumers may be unaware of the consequences of their practice, despite contributing positively to the sustainability agenda in other ways, such as recycling household-waste and demonstrating preferences for Fairtrade products. Katona (1953, cited in Kennedy and Laczniak, 2016) postulates that comprehensive information is required to make rational decisions. This situates consumers as 'a pawn', playing a game in which they do not fully understand the rules, particularly consumers who rely on mainstream options and are unable to act on their concerns (Kennedy and Laczniak, 2015: 117). A key barrier for consumers is their limited knowledge of fashion-production and how sustainability is defined, referencing concern for the environment. Weise et al. (2012) examined the literature to understand how sustainability is considered by retailers and found that sustainability was often expressed in interchangeable reference to environmentalism. This referencing is consistent with the media portrayal of sustainability as addressing environmental issues, such as recycling and local production to reduce carbonemissions, rather than concern for poverty in developing countries. This is consistent with the media portrayal of recycling and local production to reduce carbon-emissions, rather than concern for poverty in developing countries. However, it does not fully address sustainability with respect to the fashion-industry, where worker exploitation, including allegations of childlabour are at the fore of consumer consciousness. Moreover, both social and environmental concerns are juxtaposed with consumer values (Fernando and Gau, 2015), of price, style and availability. Much of the previous research examining sustainable-fashion agrees that style prohibits sustainable-fashion consumption (Ritch and Brownlie, 2016). Therefore, this paper will seek to examine consumers' approach holistically and the next section will introduce the TCV as outlined by Holbrook (1999) and colleagues.

\section{Typology of Consumer Value}

To better understand mainstream consumer sensibility, Holbrook's (1999) TCV offers new insights into the interplay of values within a specific consumption experience (Chaney et al., 2018). The typology posits that consumers seek value in their consumption and within the marketing exchange (Kotler, 1991), including not just functional attributes but also the social exchange co-created with consumers (Gupta et al., 2016; Kennedy and Laczniak, 2016). This includes a trade-off between values that are constructed to respond to individual needs and wants (Leroi-Werelds, 2019). Holbrook (1999) outlines the typology as threefold: firstly, consumer value is described as two-dimensional: extrinsic and intrinsic. Extrinsic refers to value located within the exchange, as well as displaying the product signalling cues socially; whereas intrinsic value is indicative of a lifestyle that may or not be a reality (Belk et al., 2000). Secondly, although value can be evaluated through self-orientation, the pleasure gained through ownership and using commodities to signal self-identity is also other-orientated, signalling membership to reference groups (Webb, 2007). This spans a spectrum of conformity, belonging, interest and ideology. Thirdly, value is also experienced as active and re-active: active refers to the consumer contribution through manipulation or personalisation, and re-active relates to how the product makes the consumer feel, a concept similar to 'Romantic Ethics' (Storey, 1999). 
Re-active links with the notion of passive consumption, where product attributes are used to signal value; this could extend from luxury/designer branding to sustainability. However, Leroi-Werelds (2019) notes that over the last few decades value concepts have progressed in response to the evolving consumer marketplace. Although businesses construct value within the offering of products and services, the fashion industry focuses on lower prices and speed to market. Simultaneously, consumers are also more aware of both sustainability, and allegations of exploitative practice, progressing the notion of ethical value to the fore. Although Leroi-Werelds (2019) focuses on technological advances, she also notes this is also reflected by business through CRS activities and responding to concerns for sustainability. Consequently, it could be assumed that ethical value will feature more prominently in more recent research. Having described the nature of the typology, Tables 1 and 2 display the interconnected values. To help contextualise meaning within the value types, examples from previous research are provided, taking-into-account the purposive sample (mothers working in a professional-occupation). This reflects that value constructs reflect personal circumstances that are individually constructed (Leroi-Werelds, 2019).

\section{Insert table 1 here}

Insert table 2 here

\section{Methodology}

To better understand how sustainability values are perceived and performed within family households, phenomenological interviews were adopted; an approach Becker (2018) considers underused in consumer experience research. The data derives from 28 unstructured interviews (Thomson et al., 1989) that adopt a consumer-centric view (Becker, 2018) to examine how sustainability was managed within the household, from both a practical perspective, including resources such as time and money, as well as how moralideology affected behaviours (McGouran and Protehro, 2016). The interviews lasted around an hour and allowed the participants to tell their story to understand which values were significant in the decision-making within their individual household. This was managed by two approaches: firstly, the sample was carefully selected to include those who can speak to topic (Becker, 2018); and secondly, primers were used to guide the interviews (Pink, 2005). In previous research, certain consumer characteristics have been identified as encouraging engagement; therefore, the sampling criteria approach was threefold. Firstly, women are considered as being more interested in fashion (browsing and purchasing) (Goldsmith and Clark, 2008) and more likely to adopt sustainable-behaviours (possibly related to the division of household labour where women still carry out the majority of household-chores) (do Paço and Raposo, 2010). Secondly, mothers are said to be more inclined to purchase organic food out of concern for pesticide use in food production (Atkinson, 2014) and more often are the gatekeeper for family consumption; to ensure this, the children were pre/primary age, as it was assumed that children older than 12 years would have more opinions on consumption and access to their own money (Carrigan and Szmigin, 2006). Thirdly, higher levels of education have been linked to increased knowledge of sustainable issues (do Paço and Raposo, 2010). Consequently, all the participants are mothers who work in professionaloccupations; as this cohort have been primed to consider sustainability, it was considered 
prudent to explore whether concern for production was considered in other consumption contexts. Their characteristics are presented in the Table 3.

\section{Insert table 3 here}

Typical of a phenomenological approach, the sample was purposively sought. They were not as Davies and Gutsche (2016) consider 'fringe consumers', who actively manage ethical concerns as foremost in consumption; rather, they were mothers who manage everyday lifeworlds fraught with juggling childcare, work and household responsibilities, including finances (Carrigan and Szmigin, 2006) and those commitments took precedence. As such, they relied on mainstream information and retailers that made this management easier, which Docherty et al. (2013) describe as passive involvement in ethical consumption. Therefore, the data illuminates how mainstream consumers engage with sustainable-concepts (Davies and Gutsche, 2016; McGouran and Prothero, 2016).

To elicit discussion, participants were shown fashion labels that depicted an aspect of sustainability. This is important, as the findings identified engagement with a number of sustainable-behaviours, yet low awareness of fashion sustainability. Therefore, the primers had two functions: to introduce concepts of sustainability and to illustrate fashion-retailers responses to sustainability. Table 4 presents the sustainability concept described on of the label as well as the anticipated discussions.

\section{Insert table 4 here}

The above sustainable concepts use a familiar terminology present in other consumption contexts. For example, despite the success of options to recycle a number of materials, such as glass, plastic and paper, there has been little research to examine how this transfers to fashion disposal. Additionally, organic food is now widely available in mainstream supermarkets, stimulating awareness and concern for chemicals used in production; however, how and why chemicals are used in fashion and consumer perception of this merits further examination. Lastly, there have been many high-profile allegations that UK fashionretailers rely on the exploitation of garment-workers, including child-labour, to enable lower priced garments. This is acknowledged in the media, particularly after the Rana Plaza garment factory collapsed in Bangladesh in 2014, amid been calls to better protect garment-workers (Hinsliff, 2019). This research sought to explore how notions of poor working conditions and low salaries were perceived in decision-making for family fashion purchases, anticipating value trade-offs to meet the unique needs of each household.

\section{Findings and discussion of value interplay}

The aim is to examine how consumers interpret value when negating fashion sustainability. Data were analysed using Interpretive Phenomenological Analysis to identify description of the experience, linguistical delivery (for example, sometimes the participants laughed when discussing child-labour, an illustration of discomfort rather than amusement) and interrogation to understand underlying concepts (Smith et al., 2009). Consideration included related actors in the consumption experience and dissemination of sustainability related 
behaviour, from both social settings and institutional information (Becker, 2018). Themes were developed for each participant and then collectively collated. Analysis uncovered value interplays that were evaluated depending on knowledge, practicalities and ideology; this will focus on Holbrook's (1999) TCV self/other-orientated framework to examine value interplays as experienced actively versus re-actively (passive).

Three points should be acknowledged:

Firstly, style was the most important criterion, it inspired consumption, garments were evaluated solely on style, and style would not be compromised or sacrificed for any other values. This should be taken-into-account when considering the findings, but is not a focus of this paper.

Secondly, the participants were actively involved in formal and informal redistribution networks that donated and received used-children's clothing, also not a focus of this paper.

Lastly, all of participants experienced time-poverty and competing demands, as identified by Szmigin and Carrigan (2006). Analysis included a holistic approach to participants' lifeworlds. For example, in the recycling and end-of-use section, all the values within the typology were experienced increasing confidence in the practice. This illustrates that when all the values are present, consumers feel increased satisfaction from the practice. It does not transfer to other behaviours because the marketplace does not provide guidance and options for sustainability. It does, however, provide a pathway to considering how sustainable value can be harnessed by the fashion-industry, by providing assurance to consumers that they are not contributing to exploitative practice.

\section{Self-orientated values: the trade-off between convenience, price, and moral ideology}

Within the TCV, efficiency is considered as an important measurement that is evaluated objectively and subjectively (Holbrook, 1999). Efficiency, therefore, relates to the ability to everyday management the participants developed organisational strategies as coping mechanisms. For many participants, fashion consumption was an additional duty which had to be combined with their other household chores; it was not the intrinsic and active selfindulgent treat it once was:

Without children, you can be quite independent, browsing at your leisure. Whereas having a two-year-old, you have to be quite strategic about shopping! (Participant-18)

This management resulted in relying on supermarkets to purchase more than food, to save time and money on what was now a chore:

Because the kids are busy and my husband works away during the week, I am on my own. I don't want to take all the kids out to go shopping in the evening, so, it is easier 
to pick up their clothes when I do the food shop. (Participant-25)

Similar to Carrigan and Szmigin's (2006) assertion that working mothers seek convenience in their consumption experience, the participants tended to 'grab' (Participant-1) or 'pick-up' (Participant-16) clothes for the children whilst navigating the supermarket aisles to avoid having to 'go out my way to get him clothes' (Participant-24). This differs from other fashion literature depicting fashion consumption as nourishing hedonistic and materialistic feelings (Gupta et al., 2019). As their children's continued growth necessitated more frequent consumption, inexpensive-retailers and supermarkets had reduced their proclivity to price thresholds, (Hinsliff, 2019), favouring utilitarian attributes. Conversely, for their own fashionconsumption, they wanted to express their identity through fashion (Gupta et al., 2019): often this was dictated by employment and the need to wear professional clothing. Consequently, convenience 'trumped' allegations of sustainability:

Now I am buying vests, pants and stuff in Asda, just because I am there routinely and it fits in best. I never get into town anymore, double buggy, kids on busses, it's just too difficult. Asda and Tesco, just because of the availability of them, that's saving me a trip into town with difficult kids. Even though, I'm aware, that actually, [laughing] I give lessons that you should watch what you are buying, in terms of clothes and trying not to support sweatshops. I'm hoping that that will change, [but even] if I won the lottery, and finance was absolutely no objective, then convenience would still trump a lot. (Participant-14)

As expressed above, there was suspicion that supermarket fashion allegedly derived from exploitative sources, where ethical concerns were suspended for household management and retailers that accommodated family shopping. There was a fear that knowledge might impose guilt on current behaviours, so it was easier to not 'look too closely at what H\&M are doing' (Participant-3). Therefore, the labels depicting high-street retailers as responsive to sustainability were positivily evaluated, reflecting confidence upon the retailer who facilitated access to progressive and responsive production, linking with the research by Davies and Gutsche (2016). Yet, there was frustration that this did not expand into supporting information and access for sustainability issues within the fashion industry, as experienced with the ease of recycling household-waste through doorstep collections. Many campaigns seek to encourage sustainability awareness, including recycling household-waste, reducing reliance on single-use plastics, and energy conservation. Household-recycling is supported by local authority collections and retailer campaigns that 'nudge' consumers to reconsider what is sent to landfill. It could be argued that although those practices make sustainability easy to practice; they provide an opportunity to align value concepts that are transferable to other contexts - such as consideration for waste in production, usage and disposal of fashiongarments. The data identified that recycling was routine within the households, yet also illustrated the behaviour now considered landfill, resulting in efforts to reuse materials. The importance of this service sharpens when considering this cohorts reliance of support for acting on sustainability concerns:

Recycling is difficult, it's not supported by the council. It's hard enough as a single parent, working, buying food [laughing]; how I get rid of packaging, I don't really care. It's a bad thing to say, I know. (Participant-24) 
Participant-24 was as an isolated case, but the message for recycling clearly suggests she feels a duty to recycle. Collectively, this all suggests that recycling is permeating society, consumers are being socialised to consider designations for waste. Whilst this illustrates reactivity, to the services provided, it also led to condemning others who neglected their responsibility to recycle through assuming intrinsic activity in that they owned the behaviour:

Sometimes people are just lazy. Often after weekends they just throw bottles in our [communal] bin and I'm like, why don't they recycle? (Participant-16)

The normalisation of recycling was a pivotal, where the responsibility for sustainability was enthusiastically endorsed. Excellence was experienced through the regularity of the council recycling facilities. The role of play emerged from engaging the children in sorting recycling and aesthetics were experienced through the reduction of waste in the home. Status was stimulated as recycling is considered as a socially responsible behaviour, triggering virtuous feelings of esteem, especially when the children reminded them to recycle, complying with the values taught at school. Ethical values were present as the behaviour transcends beyond personal benefits to that of wider society and the environment, and spirituality was reflected in the emotional experience of aligning household-practice with moral-ideology that contributes to the greater good. Despite the success of recycling campaigns reducing the volume of household-waste sent to landfill, there was limited awareness of fibre-recycling. Currently in the UK, M\&S, H\&M and Zara promote in-store recycling for unwanted garments: M\&S provide a voucher when their clothes are donated to Oxfam, H\&M and Zara do not provide information on what happens to donated worn garments; consequently, there is little awareness of how this contributes to the wider sustainable agenda. Although all of the participants passed used-children's clothing through formal and informal networks, an active process, this paper focuses on clothing unsuitable for reuse. It was assumed that worn garments that were unwearable could not be reclaimed:

I never know what to do with the [children's clothing]; they are generally so worn-out, what charity shop would want them? (Participant-21)

Participant-21 explains that the playful activities of children result in damaged and worn clothing which she assumes would not be accepted by charity shops; only Participant- 5 was aware that charity shops accepted unwearable garments for down-cycling. There were also feelings of guilt as it was assumed low-cost fashion was a consequence of garment-worker exploitation and child-labour. Although it was assumed sustainably produced fashion was produced to a higher quality, the reduced quality and longevity of inexpensive fashion induced notions of disposability; consequently, damaged clothing was considered as having no value:

We bought pyjamas, the button came off on the very first night [laughing]. It [was] cheap fabric, you could spit peas through it. I don't mind, I was brought up to sew [but] I don't think younger mums do. In Asda, school trousers are f3.00, who is going to recycle that? You are going to chuck it away. (Participant-10)

Participant-10 considers that sewing skills are no longer commonplace; however, she did repair those $\mathrm{f3}$ trousers! She expressed her discomfort of purchasing low-cost fashion, in 
terms of the environmental impact and suspicions of garment-worker exploitation; therefore, she assumed responsibility for extending its lifespan, again an intrinsic active process. Some felt repairing was financially beneficial, as well as responding to environmental concerns; Others noted that historically, products were repaired rather than replaced and one problem was that professional repairs were more expensive than replacing damaged goods. Indeed, even charity shops are recognising the limited value in reselling fast-fashion (Hinsliff, 2019). Although some mentioned that their skills were limited to repairing seams or sewing on buttons, as opposed to mending holes in the fabric or replacing zips. Another issue was that was some man-made fabrics, such as those used in sportswear, were difficult to work with. Participant-1 said that she felt she 'always felt good about [repairing garments]', this altruistic act conflicting with her ability to afford sustainable fashion. In defining altruism, LeroiWerelds (2019) suggests combining values of ethics and spirituality, conceptualising spirituality as escapism; however, Participant-1 expresses spirituality as moral nourishment, stimulated by an extrinsic active behaviour that is other-orientated, but satisfies intrinsic selforientation. Other participants who assumed that damaged and worn garments could not be donated to charity shops utilised the fabric of worn garments, as: cleaning cloths; restyling/upcycling garments and making accessories, such as cushion covers, from garments which provided intrinsic unique crafting experiences. These practices were active conscious decisions to maximise the lifespan of materials, protect scarce resources and minimise contributing to landfill; as such, the participants experience altruism (spirituality) by assuming intrinsic responsibility for sustainability. Involvement in recycling provides opportunities for fashion-retailers to embed textile-recycling into consumers' awareness and create new pathways for added value. Supporting textile-recycling will be particularly advantageous if fashion-retailers move to a closed-loop system where reclaimed fibres are processed into new garments.

Although the availability of products made from recycled-materials is still a niche offering, when evaluating the M\&S label describing the child's polyester-fleece made from recycledplastic-bottles, some of the participants were reminded of previous experiences. Although some felt that the quality of some recycled-materials was not as good, others acknowledged that the quality of recycled-materials was improving and were receptive to the concept. Within those discussions, there was unwillingness to compromise on values of excellence, status, ethics and spirituality; but it was style in particular, which inspired fashionconsumption and would not be sacrificed. As fashion is indicative of status where symbolic qualities supersede functional, image is an important aspect of communication (Bannister and Hogg, 2004). Although ethics and spirituality were experienced through the wide adoption of recycling waste, for fashion-consumption, these values compete with excellence and aesthetics and were considered less important. With limited experience evaluating fashion made from recycled-materials, participants drew upon other consumption-contexts of purchasing products made from recycled-materials where they experienced play, ethics and spirituality. Many examples occurred during the festive period where novelty and play are more of a focus.

I bought Christmas decorations made out of palm trees, believe it or not. (Participant13)

I have bought Christmas presents for people, [handbags] made out of plastic cartons. 


\section{(Participant-22).}

Christmas is a time of gift-giving and taking the time to source gifts that that are novel, fun and will be appreciated by the receiver is part of the process (Belk, 1988). Consumption values were enhanced through the novel use of materials, for example products made from palm trees or used cartons. The added value of play found within recycled-materials offers gifts that are 'a good conversation piece' (Participant-28), ensuring additional value attributes are transferred as evidence of thought going into the gift selection (Davies et al., 2009). This created symbolic values of play and spirituality that were transferred within gifts that were ' $a$ wee bit different' (Participant-13), 'or 'that bit special' (Participant-12). Consequently, playful experience extends post-consumption:

Cool, wow, I have never heard of plastic-bottles being made into fleeces before. (Participant- 15)

\section{That would be quite a novelty to show the kids. (Participant-9)}

The ability to transform plastic bottles into a garment was virtuously appealing and elevated the ethical and spiritual values of conscious consumers, stimulating emotions of equity and righteousness. Added value was achieved without compromising aesthetics; rather, aesthetic value was enhanced through the novel transformation of the original material. For example, reclaiming plastic bottles to make fleece fabric improved perceptions of polyester, which is often considered as an inferior material. As Participant-10 stated: 'polyester just reeks of the 1970s: electric shocks and neon colours!'. Yet, the negative connotations were transformed by novel innovation that is responsive to environmental implications and creates new consciously awareness, drawing the participants towards consumption rather than acting as a barrier. This was because the act of recycling household-waste was so ingrained within their behaviours that purchasing garments made from recycled-materials increased their notion of value:

I like the idea of the recycled. It's looking at ways that we, as a nation, or a race of people, consume, continue to consume and then dispose. (Participant-6)

Making new consumption products from recycled-materials responds to current consumption patterns as well as alleviating guilty feelings of disposability. Although values of efficiency, excellence and aesthetics must be present, the recycling-cycle was considered as socially and environmentally beneficial, reducing what was sent to landfill and making the most of the Earth's resources. Emerging awareness of the impact of fashion-production and disposal may not sit comfortably on consumers' consciences; consequently, sustainableproduction may alleviate guilt associated with exploitative production. Thus, recycledmaterials could contribute to: status, as illustrating broader concern for sustainability; esteem and ethics, through positive feelings engendered contributing to wider environmental and social concerns. Play may be addressed through the novelty of recycling, particularly when the contexts vary; for example, pineapples can be transformed into a leather like material (Peters, 2016). This provides notions of innovative novelty that can be creatively communicated through labelling; although currently unique, recycled materials expanding sustainability practice, reducing reliance on scarce resources and textile waste in landfill. 
Mainstream fashion-retailers could capitalise on this growing awareness of sustainability by creating a new value alignment where styles are selected to portray a positive image to others that indicate other-orientated status and esteem. If recycled-materials are comparable or exceed expectations of quality and aesthetics, as evident in the improved perception of polyester, there is the potential for extending this niche offering into mainstream-markets. However, unless consumers are educated on sustainability responsiveness, they will focus more on consumer centric self-orientated values (price, convenience, aesthetics and quality) rather than other-orientated values.

\section{Other-orientated values: the trade-off between household management and ambiguous allegations}

Despite the confidence expressed above in the values that shaped their everyday behaviours, where certainty was expressed in understanding consequences and outcomes, uncertainty emerged from some of the sustainable concepts described in the garment labels. Whilst style could be reflected as pertaining to self and other-orientated value, the intrinsic experience impacted more important than unsubstantiated sustainable implications, along with assumptions that sustainably produced fashion was not fashionable. This was evident in concern for sustainability includes the environmental impact of production processes, such as $\mathrm{CO}_{2}$ emissions, global transportation and the use of chemicals. Although other consumption contexts (for example, tourism, transportation, food, etc.) proactively use sustainability concepts for differentiation and value creation (McDonald et al., 2009), consumers are more aware of allegations of garment-worker exploitation than the impact fashion-production has on the environment. Given that the fashion-industry is often alleged to exploit both the environment and garment-workers, this presents production as an opportunity for value creation. However, consumers must first be made aware of the issues and how addressing sustainability within production creates added value.

Some participants were uncertain how carbon-neutral and organic production related to the fashion-industry, evidenced in their responses to the M\&S eco-factory label: 'Not a clue what that means' (Participant-10) and 'What is a Plan A factory?' (Participant-23). As high-street fashion is produced mainly in developing countries there was uncertainty as to how carbonfootprints could be reduced when supply-chains span many countries. There was also limited awareness of carbon-neutral retailing. Mainstream retailers do not have transparent supplychains, nor do they acknowledge the environmental impact of production and retailing; therefore, environmentally focused concepts were unfamiliar to the participants who were aware of organic production. As participant-23 expressed 'I am used to buying eco-friendly, I buy a lot of organic food'; there are two points of interest here: firstly, organic-production is intrinsically linked to 'eco-friendly' and secondly, this was expressed confidently as a preferred practice. This was less so when evaluating the M\&S organic cotton label; one participant stated:

I did buy organic tops in H\&M, but didn't relate that to ethical issues (Participant-3)

Another questioned: 
Organic cotton? I wouldn't immediately think that was an environmentally friendly product. (Participant-2)

The food industry has successfully positioned the concept of organic in the minds of consumers as being healthier (Ritch and Brownlie, 2016), as well as more environmentallyfriendly due to the omission of chemical pesticides in production. However, the fashionindustry does not acknowledge chemical usage. Some participants questioned the need for organic cotton given that cotton grows naturally, unaware of the use or wider social consequences of pesticidal use in production. There were concerns that sustainableproduction was used to increase the price, coupled with a reluctance to pay a higher price without assurance of avoiding exploitation of garment-workers and children. Confusion was evident in the discourse around the John Lewis label indicating 'enzyme washing':

It's a very scientific, technical term. I'm not entirely clear what it means. Is it good, rather than bad? (Participant-23)

This confusion as to whether chemical application was beneficial or detrimental to either the wearer or the environment was expressed by most- the label does not provide supporting information and this annoyed some. Confusion surrounding the implications of chemicals led to frustration and assumptions that chemical applications could be managed through laundering. A few expressed awareness that chemicals used in production may filter into water supplies or deplete the soil, but felt ill-equipped to apply this to their consumption. In contrast, most had opted for organic food when weaning their children, in an effort to avoid them digesting chemicals (Aitkinson, 2014). For some, the purity of organic status transferred to textiles, offering attributes of virtuousness and superior tactile qualities, as explained by participant-9:

I think it's better for the people that made it, it's better for the environment, it will probably feel nicer. I kind of factor all that in. (Participant-9)

Participant-9 notes that organic production values span from being 'better' for workers and the environment to offering consumers superior tactile values. This was of particular importance when selecting gifts especially for new-borns; as babies are symbolic of a new beginning, the desire to surround them with untainted pure products is understandable. There are opportunities for fashion-retailers to exploit the avoidance of chemical applications as adding value for consumers and better for the environment, particularly when styles and price are comparable:

I bought an organic t-shirt at the weekend. I was so impressed by it, it looked really nice and it was only f6.00: a reasonable price I am happy to pay. (Participant-25)

As the quotes indicate, the availability of organic fashion in mainstream-markets heightens perceptions of value, particularly when the price is not increased. The availability of organic produce in mainstream supermarkets has nudged awareness for sustainability; to see similar labels that address sustainable-production in garments from mainstream fashion-retailers led to responses such as: 'that's amazing, I just didn't know that you could get that kind of thing in regular shops' (Participant-20); 'Plan A. That's excellent. I would support that. I wasn't 
aware of it.' (Participant-27). This is in keeping with the findings from Davies and Gutsche (2016): addressing sustainability leads to loyalty and brand preference that offers mainstream consumers access to virtuous consumption, particularly when they do not have to change their habits to become sustainable.

As such, efficiency is compromised, as information is time-intensive to obtain; excellence, status and aesthetics are evaluated from style, quality and fit perspectives, with an assumed misalignment with ethics, spirituality and esteem due to limited knowledge and options in mainstream-markets. Yet, when addressing those values, as evident in the organic t-shirt, satisfaction increases. It could be argued that consumers are only being informed of sustainable-production and related attributes by the food industry (Ritch and Brownlie, 2015), whereby the transferral of sustainable attributes is somewhat skewed given that food is mainly selected for taste and health, whereas fashion is chosen for style. All of the participants reiterated that personal style would not be compromised. To sacrifice style over ambiguous ethical implications was not part of the participants' discourse, even for allegations of garment-worker exploitation.

As anticipated, the participants were more aware of alleged exploitation of garment-workers than environmental degradation, but little beyond this. Participants expressed preferences to avoid purchasing fashion that is produced exploitatively, especially child-labour. The sensitivity and complexity around these issues, including how developed countries should not dictate the working conditions and salaries of people in developing countries, given that employment is necessary to alleviate poverty. Participant-23 expressed confusion of what was meant by exploitation, or how to 'frame the parameters of exploitation'. Yet, there was much discomfort at the thought of child-labour being involved in production and Participant23 stressed that assurance that there was not, 'would be a selling point'. However, determining who made the garments they purchased was viewed as beyond any realms of possibility; their lifeworlds consisted of juggling work, childcare and household duties and they did not have perceive themselves as having the time to source relevant information. Typically, information was collated ad hoc, without time to follow through to gather knowledge of the implications. Although some consumers might rely on pricing as an indicator of exploitation (Ritch and Brownlie, 2016), campaigns have also accused higher priced brands and retailers of exploiting garment-workers. This leads consumers to assume that exploitative practice is endemic within the fashion-industry, where other-orientated values of esteem, ethics and spirituality cannot be achieved and self-orientated values are prioritised.

Yet, value can be created through addressing sustainability. Labels can help alleviate associated negative feelings, enabling consumers an affinity with garment-workers in developing countries. For example, the Global Girlfriend label presented information on a women's cooperative in Nepal that enabled garment-workers to support their families. This led to discussions of garment-workers, positioning them humanely as working mothers and creating a bond between the producer and the consumer. As working mothers, participants may experience empathic solidarity with working mothers in developing countries, increasing their concern for child-labour. Although this was not true of all of the participants, some did feel a connection as expressed by Participant-23:

That would attract me, I like things that engage with global feminist politics. I would 


\section{immediately identify and think about this. (Participant-23)}

Participant-23 uses words such as: 'attract', 'engage', and 'identify' when evaluating the label, transcending from self-orientation and self-gratification (Davies and Gutsche, 2016) to illustrate other-orientated through her desire to connect with the concept of global women's politics. This spiritual, emotional hook was typical of other responses; the label linked into charitable donations that help developing countries to alleviate poverty. However, as suggested above, it was child-labour that caused the most concern. Although the fashionindustry seeks to assure consumers that no child-labour was involved in fashion-production, allegations continue to be made (Brignall and Bulter, 2014). Similarly, when evaluating the label from the Environmental Justice Foundation, which addressed the use of children picking cotton in Uzbekistan, the participants lowered their voice and spoke empathically:

That phrase, 'childhood, lost innocence and hope', really jumps out at me. I would probably buy this now. (Participant-12)

Participant-12 has been reminded by the label that children in developing countries are often involved in fashion-production through forced labour; knowing that the garment avoids this, evokes an empathic reaction and the desire to avoid contributing to child-labour. Acknowledging consumer concerns through providing information on production can be a persuasive tool to encourage consumption, as expressed by Participant-15:

This here: protecting people and the planet, that's a good label. Forced labour, that would persuade me to buy it, definitely. (Participant-15).

As expressed above, esteem feelings were increased as sustainable-production was considered cleaner and purer, environmental protection which transferred to protecting the family. The quote also links with spirituality, also other-orientated and re-active, as well as intrinsic: capturing the embodiment of an 'emotional experience' (Park et al., 2006: 440), which is enhanced by behaviours that align with moral-ideology. Esteem is evident in accepting extrinsic social responsibility to contribute positively to the sustainable-agenda, but in doing so also provides intrinsic value.

Evaluating labels was a useful approach, as consumers seek cues in the marketplace. As fashion-production occurs at a global level, participants often feel overwhelmed by the issues; coupled with a lack of information, results in disengagement from the issues, despite willingness to contribute to positively to sustainability behaviours. The participants did not seek extensive explanations of production, as they did not have time to read this when shopping, but certain cues, such as recycling, the organic logo and acknowledging the workers involved in production, provided assurance that production is aligned with their ethical stance. Concern for sustainability is said to be rising, yet this has not manifested itself in the actual sales of sustainable-products (Carrington et al., 2010); therefore, understanding how sustainability is experienced in the household is paramount, particularly when the onus is often on consumers to determine sustainable status and action the desirable behaviour. While it can be argued that governments should do more to implement the sustainable goals into regularity frameworks to ensure that production and consumption reflects the true cost on wider society and the environment, consumers still have to navigate the current 
marketplace (Gupta et al., 2016). The fashion industry can learn from how the language in some of the labels created virtuous value alignment, transcending self-orientation and selfgratification to focus on other-orientated values created through progressive production and communicated positively. This emotive communicative tool is used by social enterprises and charitable organisations, especially those that help developing countries to alleviate poverty. Without transparency in fashion-production, value will be constructed without meaning and consumers will continue to feel frustration.

\section{Concluding comments}

This research sought to explore how mainstream consumers evaluate facets of sustainability in their everyday lifeworlds and how this informs their contributions to the sustainability agenda. The evidence from the participants illuminated upon negotiating values, harnessing knowledge from familiar household contexts to transferring key concepts through a fashion lens. Although extant research has examined attitudes for sustainability, limited research has investigated sustainability experiences holistically within household-behaviours (Becker, 2018). This research offers new insight into how sustainability is perceived and evaluated, and applied to fashion, evaluated by uncovering the unique situational moderating factors underpinned by consumer value (Leroi-Werelds, 2019), and there is much to learn how everyday deliberations are interpreted to inform practice. This advances previous arguments that sustainable-fashion is hindered by limited styles (Ritch and Brownlie, 2016) by offering opportunities for value creation through sustainable-production. Participants expressed aesthetics as the most important criterion for fashion-consumption, noting that style Is an indication of self-identity, projecting social and professional status (McGouran and Prothero, 2016). Yet, the research identified a desire to participate in sustainable-practice, encouraged by campaigns and practical resources, alongside tentative, conflicted and circumstantial behaviours. Therefore, as postulated by Leroi-Werelds (2019), they were not dismissive of ethical production, rather they relied on low pricing as part of their household management (low pricing and convenience), indicating they would reward fashion retailers who address sustainability. This paper contributes to growing discourse around sustainability in mainstream-markets (Davies and Gutsche, 2016). Focusing on those who are not typically engaged with sustainability (McGouran and Prothero, 2016) illustrates a progression from niche markets to broader social awareness. Wider audiences are engaging with sustainability as campaigns to inform consumers of production and consumption implications are gaining momentum (Becker, 2018).

The participants did not apply a deliberate approach to consumption, as per McGouran and Prothero (2016); similar to research by Davies and Gutsche (2016) they focused on consumercentric values, such as time-saving, price, and primarily style, over which they had more certainty. In terms of understanding how values are negotiated and traded within household consumption, this research extends our knowledge by demonstrating that sustainability practice fluctuates, depending on the information provided and the support available; consequently, tangible outcomes were prioritised, such as maximising resources and alternative routes for waste captured within efficiency, excellence, status, esteem, play and aesthetics; and yet with careful positioning labels and related marketing materials, can situate ethical and spiritual values alongside status, esteem, play and aesthetics. In particular, 
spirituality - the contribution to the greater good stimulated by emotive language - was an important finding. Note the confidence and self-appointed involvement in recycling and preferences for goods made from recycled-fabrics, against the uncertainty of unfamiliar concepts (chemical-usage) and allegations of exploitation. Although this progresses consumers from passive consumption, consumers will fluctuate between acting sustainably and unsustainably, depending on guidance, options and their individual circumstances. This advances the TCV by acknowledging that although all values must be present to ensure satisfaction, some consumption contexts focus more acutely on certain values; for fashion this includes aesthetics, status and esteem. Secondly, the TCV assumes equality in evaluation, yet this research reveals that information on the impact of fashion-production, or availability of sustainable fashion, is not as advanced in mainstream markets as in other contexts; therefore, ethics and spirituality cannot emerge to the fore.

It is here that fashion-producers and retailers can create value, by aligning fashion and sustainability values to gain competitive advantage through managing information flows that deepen consumers understanding of fashion production (Mutum et al., 2019). Leroi-Werelds (2019) advances discourse of the TCV through recognition that the consumer marketplace has changed, something particularly relevant given the decreasing cost of mainstream fashion. Similarly, an update was necessary to reflect growing concern for sustainability and climate change. This paper exhibits concern which is juxtaposed with continued allegations of exploitation perpetrating the fashion industry as inherently unsustainable. The participants express preferences for sustainability within their narratives, along with uncertainty of how to apply sustainable fashion consumption. Therefore, sustainability behaviours were practiced post-consumption as a means to minimise their sustainability impact. This has the potential for co-creating experience-based interactions (Choi et al., 2016), endorsing trust and minimising the risk (Leroi-Werelds, 2019) of contributing to exploitation of the environment and garment-workers. Expanding on Davies and Gutsche (2016), who conclude that although habits are central to consumption behaviours, amid a reluctance to adopt change that may further impede their busy lifeworlds, retailers and brands who facilitate sustainable-behaviours can benefit from a 'halo effect', supporting intent for sustainability. Sustainable-products in mainstream-markets endorse the retailer who facilitates an alignment of consumption with ideology, acting as a gatekeeper for sustainability. For brands to create and align value with consumers, support for sustainability must enhance notions of virtuousness, rather than guilt.

Adopting a phenomenological methodology generated rich interpretive data of ideographic household experiences that incorporated utilitarianism and hedonism (Leroi-Werelds, 2019; Chaney et al., 2018). Differing from other phenomenological approaches, participants were not required to be ethically focused; they were mothers whose lifeworlds consisted of juxtaposing childcare and child-demands, work and household responsibilities (Carrigan and Szmigin, 2006). Yet, they describe embracing aspects of sustainability and questioning aspects of production and disposal, as well as feeling inspired to transfer sustainable-behaviours from one context to another. This sheds light on how mainstream consumers evaluate facets of sustainability and it is here that adopting an experiential approach, such as Holbrook's TCV (1999), offered a number of benefits, particularly as consumption, and especially fashion, is a consequence of utilitarian and hedonistic values (Chaney et al., 2018). Hedonism was less relevant to purchasing fashion for the children, where self-orientated consumer-centric 
values were more prominent (Gupta et al., 2016). Yet, the findings illustrate that value is not solely viewed through a singular intrinsic lens, but extrinsically to include concepts of otherorientated ethics (to consider the environment), esteem (altruistic and avoiding guilt) and spirituality (protecting the sacredness of the planet). As such, engaging with creating coconstructed value by responding to sustainability concerns can strengthen brand value (Choi et al., 2019) through aligning fashion with sustainability values.

This illuminates upon axiological issues of ethics and morality (Bolis et al., 2014) and the question of whether consumers benefit through inexpensive-fashion, which does not reflect the true cost to either the environment or those involved in production (Gupta et al., 2016; Memery et al., 2005)? It could be argued that consumers are deliberately kept in the dark over production practices. Although there was high awareness of exploitation including childlabour in fashion-production, participants struggled to conceptualise the full implications; they sought cues that could provide insight and therefore when evaluating labels that 'protect' people and the planet, and enable women in developing countries to have employment, the response was positively empathic; often consumer-centric values were enhanced through contributing positively to those in need and making what was considered charitable donations through consumption. This was created through social exchange: progressive behaviour underpinned by civic responsibility, that transcends self-orientation and self-gratification (Davies and Gutsche, 2016) to values that are other-orientated, with altruism (spirituality) imbued within the consumption act - the consumer embodies contributions to the greater good (Storey, 1999). This is experienced intrinsically, positive feelings, and extrinsically, by indicating a progressive sustainable-lifestyle that may not extend any further. Therefore, although consumers benefit from low prices of fashion, they are unaware of the consequences of the production choices made by retailers; they are also limited by what is available from mainstream fashion-retailers. Such limitations are not only market driven, but a consequence of lifeworld management experienced within the negotiation and trading of values.

Limitations can be assumed due to the small cohort under investigation; however, the purpose of a phenomenological approach is not to make generalisations, but to better understand experiences 'as lived' (Thomson et al., 1989). This was enhanced as the sample selection was advised by the extant literature as having an increased interest in sustainability, and had adopted behaviours which reflect this, albeit in other consumption-contexts. Future research could explore value transferal constructs within other cohorts, such as younger consumers who purchase fast-fashion, or other contexts, such as how concepts of sustainability differ when purchasing household goods or toys. The research sought to investigate whether interest in sustainability had transcended consumption-contexts and behaviours and found this limited for fashion, due to insufficient information and guidance. It does, however, provide pathways for the fashion-industry to address sustainability. This could include addressing the following on labels, potentially with links to online video that enhance co-created experience-based interactions (Choi et al., 2019):

- Introducing the garment-production-workers involved in production and using this to encourage consumption through explaining the benefits of employment, salaries 
respective of their country's economy and an assurance that children were not involved in production.

- As some consumers misunderstand the value of sustainable-fashion, fashion-brands and retailers must expand upon the benefits of sustainable-fashion-production as creating value. for example, how organic cotton benefits the environment and has a social element.

- Examples of carbon emissions, chemical usage and how this is avoided by carbonneutral factories, organic-production could be illustrated by figures outlining reductions, social and environmental benefits of organic-production, use of recycled or reclaimed materials and carbon-offsetting.

\section{References}

Atkinson, L. (2014), "Green moms: the social construction of a green mothering identity via environmentally advertising appeals", Consumption Markets \& Culture, Vol. 17 No. 6, pp.553572.

Banister, E.N. and Hogg, M.K. (2007), "Consumers and their negative selves, and the implications". Hines, T. and Bruce, M. Fashion Marketing Contemporary Issues. Amsterdam; London: Butterworth Heinemann, pp.217-227.

Becker, L. (2018), "Methodological proposals for the study of consumer experience", Qualitative Market Research: An International Journal, Vol. 21 Issue: 4, pp.465-490.

Belk, R.W. (1988), "Possessions and the Extended Self", Journal of Consumer Research, Vol. 15, pp.139-168.

Belk, R.W., Ger, G, and Askegaard, S. (2000), "The missing streetcar Named Desire",

Bick, R., Halsey, E., and Ekenga, C.C. (2018). The global environmental injustice of fast Fashion. Environmental Health. Vol. 17 No. 92.

Bolis I., Morioka S. N. and Sznelwar L.I., (2014), "When sustainable development risks losing its meaning. Delimiting the concept with a comprehensive literature review and a conceptual model“, Journal of Cleaner Production, Vol. 83, pp.7-20.

Bray, J., Johns, N. and Kilburn, D. (2011), "An exploratory study into the factors impeding ethical consumption", Journal of Business Ethics, Vol. 98 No. 4, pp.597-608.

Brignall, M and Butler, S. (2014), "Bangladesh garment factories still exploiting child-labour for UK products", The Guardian. available from: https://www.theguardian.com/world/2014/feb/06/bangladesh-garment-factories-childlabour-uk [assessed 30 May, 2019]

Carrigan, M and Szmigin, I. (2006) "“Mothers of invention": maternal empowerment and convenience consumption", European Journal of Marketing, Vol. 40 No. 9/10, pp.1122-1142. 
Carrington, M.J., Neville, B.A., and Whitwell, G.J. (2010), "Why ethical consumers don't walk their talk: Towards a framework for understanding the gap between the ethical purchase intentions and actual buying behaviour of ethically minded consumers", Journal of Business Ethics, Vol. 97 No. 1, pp.139-158.

Chaney, D., Lunardo, R., and Mencarelli, R. (2018), "Consumption experience: past, present and future", Qualitative Market Research: An International Journal, Vol. 21 Issue: 4, pp.402420.

Choi, E., Ko, E., and Kim, A. J. (2016), "Explaining and predicting purchase intentions following luxury-fashion brand value co-creation encounters. Journal of Business Research, Vol. 69 No. 12, pp.5827-5832.

Davies, F. (1994), "Fashion, Culture and Identity", University of Chicago Press: San Diego

Davies, G., Whelan, S., Foley, A. and Walsh, M. (2009), "Gifts and gifting", International Journal of Management Reviews, Vol. 12 No. 4, pp.413-434.

Davies, I.A., and Gutsche, S. (2016),"Consumer motivations for mainstream "ethical" consumption", European Journal of Marketing, Vol. 50 No. 7/8, pp.1326-1347.

do Paço, A.M.F. and Raposo, M.L.B. (2010), "Green consumer market segmentation: empirical findings from Portugal", International Journal of Consumer Studies, Vol. 34 No. 4, pp.429-436.

Docherty, B., Davies, I. A. and Tranchell, S. (2013), "Where now for fair trade?" Business History, Vol. 55 No. 2, pp.161-189.

Fernando, E.R. and Gau, J.R. (2015), "Concrete and abstract goals associated with the consumption of environmentally sustainable products", European Journal of Marketing, Vol. 49 No. 9/10, pp.1645-1665.

Goldsmith, R.E. and Clark, R.A. (2008), "An analysis of factors affecting fashion leadership and fashion opinion seeking", Journal of Fashion Marketing and Management, Vol. 12 No. 3, pp.308-322.

Gupta. S., Gwozda, W. and Gentry, J. (2016), "The role of style versus fashion orientation on sustainable apparel consumption", Journal of Macromarketing, Vol. 39 No.2, pp.108-207.

Hansen, T. (2005), "Perspectives on consumer decision-making: An integrated approach", Journal of Consumer Behaviour. Vol 4 No 6, pp.420-437.

Harrison, R., Newholm, T., and Shaw, D. (2005) "The Ethical Consumer", Sage: London.

Hinsliff, G. (2019), “Cheap and cheerful: why there's more to Primark's success than you thought, The Guardian, Available from: https://www.theguardian.com/business/2019/may/28/more-to-primark-success-than-youthought? [Accessed 30 May, 2019] 
Holbrook, M.B. (1999), "Introduction to consumer value", Holbrook, M.B, Consumer Value A Framework for Analysis and research, London: Routledge, pp.1-29.

Kennedy, A.M. and Lacniak, G.R. (2016) "Conceptualisations of the consumer in marketing thought", European Journal of Marketing, Vol. 50 No. 1/2, pp.166-188.

Kotler, P. (1991), “Marketing management", 7th ed, Englewood Cliffs NJ: Prentice-Hall.

Leroi-Werelds, S. (2019), "An update on consumer value: State of the art, revised typology, and research agenda", Journal of Service Management, Vol. 30 No. 5, pp.650-680.

McDonald, S., Oates, C., Thyne, M., Alevizou, P. and McMorland, L.A. (2009). "Comparing sustainable consumption patterns across product sectors". International Journal of Consumer studies. Vol. 33 No. 2, pp.137-145.

McGouran, C. and Prothero, A. (2016), "Enacted voluntary simplicity - exploring the consequences of requesting consumers to intentionally consumer less", European Journal of Marketing, Vol. 5, pp.189-212.

Memery, J., Megicks, P. and Williams, J. (2005) "Ethical and social responsibility issues in grocery shopping: a preliminary typology", Qualitative Market Research: An International Journal, Vol. 8 No. 4, pp.399-412.

Mutum, D., Ghazali, E. and Putit, L. (2019). "Information, The Missing Link Between Innovation and Sustainability" The Bottom Line, Vol. 32 No 4, pp. 249-252.

Park, E.J., Kim, E.Y. and Forney, J.C. (2006), "A structural model of fashion-orientated impulse buying behavior", Journal of Fashion Marketing and Management, Vol. 10 No. 4, pp.443-446.

Piamphongsant, T. and Mandhachitara, R. (2008), "Psychological antecedents of career women's fashion clothing conformity"' Journal of Fashion Marketing and Management, Vol. 12 No. 4, pp.438-455.

Pink, S. (2005). "Doing visual ethnography". 2nd ed. London: Sage.

Ratneshwar, S, Mick, D.G. and Huffman, C, The why of consumption, London: Routledge, pp.98-119.

Ritch E.L, and Brownlie D. (2016), "Everyday dramas of conscience navigating identity through creative neutralisations", Journal of Marketing Management, Vol. 32 No. 9/10, pp.1012-1032.

Rivoli, P. (2009), "The travels of a T shirt in the global economy. An economist examines the markets, power, and politics of world trade". $2^{\text {nd }}$ Ed, New Jersey: John Wiley \& Sons.

Schiffman, L.G. and Kanuk, L.L. (2010), "Consumer behavior", 10 th Ed, New Jersey: Prentice Hall.

Smith, J. A., Flowers, P. \& Larkin, M. (2009). “Interpretive Phenomenological Analysis: Theory, 
Method and Research". London: Sage.

Stern, N. (2006), "Stern review on the economics of climate-change", Office of Climatechange, available from: http://webarchive.nationalarchives.gov.uk/+/http:/www.hm> treasury.gov.uk/sternreview_index.htm [accessed 30 May 2019]

Storey, J. (1999), "Cultural consumption and everyday life"' London: Arnold.

Szmigin, I. and Carrigan, M. (2006). "Consumption and community: choices for women over Forty". Journal of Consumer Behaviour. Vol. 5 No. 4. pp.292-303.

Thomson, C.J., Locander, W.B. \& Pollio, H.R. (1989), "Putting consumer experience back into consumer research: The philosophy of existential phenomenology", Journal of Consumer Research, Vol. 16 No. 2, pp.133-146.

Webb, B. (2007), "Retail brand marketing in the fashion industry", Hines, T. and Bruce, M, Fashion Marketing Contemporary Issues, London: Butterworth-Heinemann, pp.107-129.

Weise, A., Kellner, J., Lietke, B., Toporowski, W. and Zielke, S. (2012), "Sustainability in retailing - a summaritive content analysis", International Journal of Retail and Distribution, Vol. 40 No. 4, pp.318-335.

World Commission on Environment and Development (1987), "Our Common Future", Oxford: Oxford University Press. 


\section{Experiencing fashion: The interplay between consumer}

\section{value and sustainability}

\section{Table 1: TCV-Self-orientated}

\begin{tabular}{|c|c|c|}
\hline & Extrinsic & Intrinsic \\
\hline Active & $\begin{array}{l}\text { Efficiency (Convenience) } \\
\text { Efficiency, can be summarised as 'time, money } \\
\text { and effort' (Schiffman and Kanuk, 2010: 23). } \\
\text { Lifestyles are said to induce time-poverty, } \\
\text { particularly for working mothers reducing } \\
\text { allocating time for decision-making and } \\
\text { shopping (Carrigan and Szmigin, 2005). They } \\
\text { may seek on shortcuts to manage their } \\
\text { numerous responsibilities, such as purchasing } \\
\text { fashion from the supermarket as they are } \\
\text { routinely shopping for food. Davies and } \\
\text { Gutsche (2016) concluded that the availability } \\
\text { of Fairtrade products in supermarkets enabled } \\
\text { mainstream consumers to purchase ethical } \\
\text { products. }\end{array}$ & $\begin{array}{l}\text { Play (Fun) } \\
\text { Play is active and self-orientated, driven by } \\
\text { intrinsic pleasure, desire and satisfaction (Belk } \\
\text { et al., 2000). Play could manifest itself in both } \\
\text { fashion and sustainability, with fashion being } \\
\text { the playful act of dressing up and } \\
\text { experimenting with styles and sustainability } \\
\text { incorporating new creative behaviours, such as } \\
\text { re-use, novelty and handicrafts. }\end{array}$ \\
\hline Reactive & $\begin{array}{l}\text { Excellence (Quality) } \\
\text { Excellence includes evaluating price, quality } \\
\text { and convenience (Hansen, 2005), where price } \\
\text { is used as an indication of quality (Aspers, } \\
2008 \text { ) to obtain the best quality-price ratio } \\
\text { (Harrison et al., 2005). Price has an implication } \\
\text { on ethics, as ethical production is considered } \\
\text { more expensive, with the products perceived } \\
\text { of a lower quality (Bray et al., 2011). }\end{array}$ & $\begin{array}{l}\text { Aesthetics (Beauty) } \\
\text { The importance of aesthetics for fashion and } \\
\text { related behaviours is overwhelmingly } \\
\text { represented in the fashion literature } \\
\text { (Goldsmith and Clark, 2008). McGouran and } \\
\text { Prothero (2016) found that reducing } \\
\text { consumption impacts on physical appearance, } \\
\text { challenging one's sense of self and well-being, } \\
\text { because consumption is used to construct self- } \\
\text { identity, illustrating that aesthetics are other- } \\
\text { orientated through social construction. }\end{array}$ \\
\hline
\end{tabular}




\begin{tabular}{|c|c|c|}
\hline & Extrinsic & Intrinsic \\
\hline Active & $\begin{array}{l}\text { Status (Success, Impression, Management) } \\
\text { Status is actively sought as an other- } \\
\text { orientated display of personal attributes of } \\
\text { lifestyle, identity and belonging, where } \\
\text { symbolism is as important as utility } \\
\text { (Piamphongsant and Mandhachitara, 2008). } \\
\text { Social expectations will be accepted or } \\
\text { rejected; this could include recycling activities } \\
\text { and campaigns that raise awareness for } \\
\text { sustainability. }\end{array}$ & $\begin{array}{l}\text { Ethics (Virtue, Justice, Morality) } \\
\text { Ethical concern is also other-orientated } \\
\text { expressed within concern for others, extending } \\
\text { to the environment. Concern for sustainability } \\
\text { is said to be rising, yet this has not manifested } \\
\text { itself in the actual sales of sustainable- } \\
\text { products (Carrington et al., 2010); therefore, } \\
\text { understanding how sustainability is } \\
\text { experienced in the household is paramount, } \\
\text { particularly when the onus is often on } \\
\text { consumers to determine sustainable status } \\
\text { and action the desirable behaviour. }\end{array}$ \\
\hline Reactive & $\begin{array}{l}\text { Esteem (Reputation, Materialism, Possessions) } \\
\text { Esteem is experienced extrinsically and is also } \\
\text { re-active to social expectations. Fernando and } \\
\text { Gau (2015) found that esteem motivated } \\
\text { sustainable-behaviours, through the desire to } \\
\text { protect natural resources for future } \\
\text { generations. }\end{array}$ & $\begin{array}{l}\text { Spirituality (Faith, Ecstasy, Sacredness, Magic) } \\
\text { Spirituality is other-orientated and reactive, } \\
\text { the embodiment of the 'emotional experience' } \\
\text { for intrinsic value (Park et al., 2006: 440), } \\
\text { which is enhanced by behaviours that align } \\
\text { with moral-ideology. Spirituality may be } \\
\text { experienced through recognition that } \\
\text { behaviours contribute positively to the } \\
\text { sustainable-agenda. }\end{array}$ \\
\hline
\end{tabular}

(Holbrook 1999: 12) 
Table 3: Participants characteristics

\begin{tabular}{|c|c|c|c|}
\hline $\begin{array}{l}\text { Participant } \\
\text { number (age) }\end{array}$ & $\begin{array}{l}\text { Occupation (work commitment: full / part time/ number } \\
\text { demotes number of days or hours worked per week) }\end{array}$ & $\begin{array}{l}\text { Family structure (age of } \\
\text { children) }\end{array}$ & Marital status \\
\hline $1(41)$ & Befriending service coordinator ( 32 hours) & $14(f), 11(m), 8(f), 8$ (f) & Couple \\
\hline $2(28)$ & Probationary teacher (full-time) & $8(f)$ & Single \\
\hline $3(43)$ & Lecturer (full-time) & $8(f), 5(m)$ & Couple \\
\hline $4(43)$ & Manager (full-time) & $10(\mathrm{~m}), 7(\mathrm{f})$ & Couple \\
\hline $5(42)$ & Lecturer (part-time) & $8(m), 6(f)$ & Couple \\
\hline $6(37)$ & Financial services compliance officer (part-time) & 12 (f), 9 (f) & Couple \\
\hline $7(40)$ & Admin secretary (part-time) & $9(m), 6(f)$ & Couple \\
\hline $8(47)$ & Company director (45 hours) & $9(f), 6(m)$ & Couple \\
\hline $9(34)$ & Student guidance advisor (18 hours) & $3(f), 1$ (f) & Couple \\
\hline $10(48)$ & Tourism (part-time) & $9(f), 6(f)$ & Couple \\
\hline $11(39)$ & Primary teacher (17.5 hours) & 6 (f), 4 (f) & Couple \\
\hline $12(39)$ & Solicitor ( 22.5 hours) & $8(\mathrm{~m}), 5(\mathrm{f})$ & Couple \\
\hline $13(47)$ & Police operations coordinator (18 hours) & $10(f), 7(m)$ & Single \\
\hline $14(36)$ & Secondary school teacher (3 days per week) & $3(f), 2(m), 2(f)$ & Couple \\
\hline $15(38)$ & Book keeper/administrator (21 hours) & $6(\mathrm{~m}), 4(\mathrm{f})$ & Couple \\
\hline $16(39)$ & Accounts assistant ( 28 hours) & $4(\mathrm{~m}), 2(\mathrm{f})$ & Couple \\
\hline $17(28)$ & Retail (8 hours) & $8(f), 4(m)$ & Couple \\
\hline $18(40)$ & Physiotherapy lecturer (19.5 hours) & 2 (f), pregnant & Couple \\
\hline $19(42)$ & University administrator (18.5 hours) & $6(\mathrm{~m}), 5(\mathrm{~m})$ & Couple \\
\hline $20(39)$ & Social researcher (16 hours) & 6 (f), 4 (f), 6 months (f) & Couple \\
\hline $21(34)$ & Chartered accountant ( 28 hours) & $15(\mathrm{~m}), 12(\mathrm{f}), 4(\mathrm{~m}), 3(\mathrm{~m})$ & Couple \\
\hline $22(48)$ & Solicitor/mediator (full-time) & $16(m), 14(f), 11(m)$ & Couple \\
\hline $23(42)$ & Senior lecturer (full-time) & $2(f)$ & Couple \\
\hline $24(36)$ & Research administrator (full-time) & $5(\mathrm{~m})$ & Single \\
\hline $25(40)$ & Lecturer (18 hours) & $9(m), 5(f)$ & Couple \\
\hline $26(43)$ & Administrator (28 hours) & $4(\mathrm{~m})$ & Couple \\
\hline $27(44)$ & Lecturer (21 hours) & $6(\mathrm{~m}), 3(\mathrm{f})$ & Couple \\
\hline $28(42)$ & Solicitor (full-time) & $6(\mathrm{~m}), 3(\mathrm{~m}), 11$ months $(\mathrm{m})$ & Couple \\
\hline
\end{tabular}

Table 4: The content of the primers and anticipated discussion

\section{Label}

M\&S child's fleece made from recycled-plastic-bottles

M\&S eco-factory label

M\&S organic cotton school shirts John Lewis enzyme washed child's top

Environmental Justice Foundation (EJF) charity t-shirt Global Girlfriend woman's top (Fairtrade and organic)

\section{Anticipated discussion}

To encourage discussions of recycling

The label describes carbon-neutral production and may inspire consideration for reducing carbon-emissions in fashion-production To encourage consideration for organic cotton production To stimulate discussions for chemical applications

The label describes child exploitation within the cotton industry and may lead to reflections on child-labour Presented information about the woman workers non-profit, fairtrade organisation in Nepal and may encourage discussion of garment-workers 